\title{
Heinrich Zimmermann and the Proposed Voyage of the Imperial and Royal Ship Cobenzell to the North West Coast in 1782-1783'
}

\section{Robert J. King}

\begin{abstract}
Johann Heinrich Zimmermann (1741-1805) a navigué sur le Discovery lors du troisième voyage de James Cook au Pacifique (1776-1780) et a écrit un compte du voyage, Reise um die Welt mit Capitain Cook (Mannheim, 1781). En 1782 il a été invité par William Bolts à participer à un voyage à la côte nord-ouest de l'Amérique partant de Trieste sous les couleurs autrichiennes impériales. Ce voyage était conçu comme réponse autrichienne aux voyages de Cook, un voyage impérial de découverte autour du monde qui devait comprendre l'exploitation des possibilités commerciales du commerce des fourrures sur la côte nordouest et le commerce avec la Chine et le Japon. Zimmermann a été rejoint à Trieste par trois de ses anciens compagnons de bord sous Cook -- George Dixon, George Gilpin et William Walker, chacun destiné à naviguer comme officier sur le navire impérial et royal Cobenzell. Les lettres et le journal de Zimmermann qui ont survécu fournissent une source valable à cette étude des origines du commerce maritime des fourrures sur la côte nord-ouest.
\end{abstract}

On 24 July 1782, George Dixon wrote from Vienna to Heinrich Zimmermann, his former shipmate on the Discovery during James Cook's 1776-1780 expedition to the North Pacific:

Dear Harry, Yours I Rec'd, and am glad you have Resolution, like the Honest Sailor which I allways have taken you for, and are willing to be doing sum thing both for your self and the Country. By this time I expect you will be in Trieste, and have seen Mr Walker... As you may be a little mistaking in Regard to the Voyage and its Nature, Mr Walker can give you sum Information and the Remainder, I shall Acquent you with, when I see you which I expect to be shortly. I am, Dear Harry, Yours \&ca, Geo. Dixon.2

1 Presented at the Canadian Nautical Research Society Conference, Pacific Navigation, Victoria, British Columbia, 12-15 August 2009.

2 George Dixon to Henry Zimmermann, Vienna, 24 July 1782; International Institute of Social History (IISH), Amsterdam, Georg von Vollmar Papers, Anhang: Nachlass von Johann Heinrich Zimmermann, A1, ff.7-9 on-line (as at 8 June 2011) at: http://www.iisg.nl/

The Northern Mariner/le marin du nord, XXI No. 3, (July 2011), 235-262 
Both Dixon and Zimmermann had been recruited for a voyage to the North West Coast of America and round the world on the Imperial and Royal Ship Cobenzell. The voyage was to be undertaken for Emperor Joseph II by the Imperial Asiatic Society of Trieste, otherwise known as the Triestine Society, a company set up and run by William Bolts for the purpose of carrying out this voyage. ${ }^{3}$

William Bolts, born in Amsterdam of German descent in 1739, had spent the years from 1759 to 1768 in India in the service of the English East India Company. After falling out with the Honourable Company he was sent back to England, where he became one of its severest critics. He engaged in a long and expensive legal battle seeking redress from the Company, and published Considerations on India Affairs, a book exposing in detail the abuses of the company's rule in India. Having thus thoroughly burnt his bridges with the British establishment, he offered his services to the government of the Holy Roman Empire through its representative in London, Count Louis de Belgioioso, putting forward a proposal for re-establishing Austrian trade with India from the Adriatic port of Trieste (thus avoiding treaty bans forbidding trade with India from the Empire's Belgian ports). The Imperial government accepted his proposal and, after granting him naturalization as an Austrian subject, commissioned him as a lieutenant-colonel and provided him with a ten-year charter, and from June 1776 to May 1781 Bolts was engaged in this business, making the voyage to India in the East Indiaman, Giuseppe $e$ Teresa (he set out from the more convenient Tuscan port of Leghorn, rather than Trieste). ${ }^{4}$ After his return from India in May 1781, Bolts went to the Austrian Netherlands to negotiate with his Belgian financial partners, headed by Charles Proli, with whom he had fallen into dispute, and to discuss the future of his charter at audiences with Joseph II, who was then visiting Belgium. It was reported in the press that:

Mr. Bolts meets with encouragement from the Emperor in establishing an India trade at Trieste. It is supposed he will make a very considerable fortune in five or six years. He is to employ whatever ships he pleases, with no other proviso, than touching at that port, landing what he pleases, registering the rest at the custom house, and sailing with it wherever he likes. He is to have the supply of all the Austrian dominions. He has strongly urged the Emperor to double the plan: to have a seat of it at Trieste, for the contiguous dominions and the Italian demand; and the other at Ostend for Flanders and the foreign

collections/zimmermann-papers.php

3 G. P. V. Akrigg and Helen B. Akrigg, in British Columbia Chronicle, 1778-1846 (Vancouver: Discovery Press, 1975), 33, wrote: "The whole Bolts affair remains pretty much a mystery."

4 Barry M. Gough and Robert J. King, "William Bolts: An Eighteenth Century Merchant Adventurer," Archives: The Journal of the British Records Association XXXI, no.112 (April 2005); John Everaert, "Willem Bolts: India Regained and Lost: Indiamen, Imperial Factories and Country Trade (1775-1785)," in K.S. Mathew (ed.), Mariners, Merchants, and Oceans: Studies in Maritime History (New Delhi: Manohar, 1995), 363-369; Michal Wanner, "Imperial Asiatic Company in Trieste-The Last Attempt of the Habsburg Monarchy to Penetrate East Indian Trade, 1781-1785," 5th International Congress of Maritime History, Royal Naval College, Greenwich, 23-27 June 2008. 
trade; but as it is determined to have the port of Antwerp restored, that scheme is postponed till that event takes place. ${ }^{5}$

At an audience with the Emperor in Brussels on 28 July 1781, Bolts and his financial partners agreed to the transformation of their association into a share company, and in August Bolts surrendered his charter to the new Imperial Company of Trieste and Antwerp for the Commerce of Asia in return for a loan of 200,000 florins and the right to send two ships on his own account to China. ${ }^{6}$

Bolts now became enthused with the idea for a voyage to the North West Coast of America to engage in the trade in sea otter furs to China and Japan. In Bombay in 1778, Bolts had bought a ship, which he called the Kaunitz, from one Andrew Reid, and had sent it to Canton under John Joseph Bauer, the master of the Giuseppe e Teresa, with Reid as supercargo. ${ }^{7}$ Bauer took Reid in the Kaunitz back to Leghorn and in 1780 Reid made another voyage to Canton, arriving there in October, where he met his brother, John, who had come from India on his own ship and who was installed as agent of the Imperial Company and Austrian consul. ${ }^{8}$ John Reid no doubt learned of the sensation caused there the previous December when crews of the ships of James Cook's third expedition, Resolution and Discovery, enjoyed unexpected success in selling for high prices the sea otter pelts they had obtained for trinkets on the North West Coast. ${ }^{9}$ Bolts was presumably given a report on this from Andrew Reid after the Kaunitz arrived back at Leghorn on 8 July 1781, Bolts himself having arrived there on 6 May from India on the Giuseppe e Teresa. ${ }^{10}$

$5 \quad$ The Freeman's Journal (Dublin), 8 May 1781.

6 Bolts's two-hour long interview with the Emperor was reported in Gazzetta Universale (Florence), 11 Agosto 1781. The "Société Impériale pour le Commerce Asiatique de Trieste et d'Anvers" described in David Macpherson, The History of the European Commerce with India (London, 1812), 316. Guillaume Bolts, Recueil de pièces authentiques, relatives aux affaires de la ci-devant Société impériale asiatique de Trieste, gérées à Anvers (Antwerp, 1787), 60-65; N.L. Hallward, William Bolts, A Dutch Adventurer under John Company (Cambridge: Cambridge University Press, 1920), 190-95.

7 Franz von Pollack-Parnau, "Eine österreich-ostindische Handelskompanie, 1775-1785: Beitrag zur österreichische Wirtschaftsgeschichte unter Maria Theresia und Joseph II," Vierteljahrsschrift für Sozial- und Wirtschaftsgesichte, Beiheft 12 (Stuttgart, 1927), 42.

8 A. R. Williamson, "John Henry Cox: the Founder of EWO," in A. R. Williamson, Eastern Traders: Some Men and Ships of Jardine Matheson \& Company and their Contemporaries in the East India Company's Maritime Service, (Ipswich, Jardine Matheson, 1975), 1-35, nb 10. Charles Samuel de Constant et Louis Dermigny, Les Memoires de Charles de Constant sur le Commerce a la Chine (Paris, SEVPEN, 1964), 343.

9 Catherine Gaziello, L'expédition de Lapérouse, 1785-1788, (Paris: CTHS-Comité des Travaux Historiques et Scientifiques, 1984), 49-50.

10 After Bolts purchased the Kaunitz in Bombay in March 1778, Bauer took Reid in her to Canton, from whence she sailed for Leghorn at the beginning of January 1779, arriving on 30 June, where she was sold on to the Proli consortium; she departed Leghorn 26 March 1780 under Andrew Reid and arrived in October at Canton, whence she departed 1 January 1781, arriving back at Leghorn on 8 July and at Trieste on 23 September: Gazzetta Toscana (Florence), 5 Luglio 1779 and 10 Ottobre 1781; The London Chronicle, 8 July 1779; 


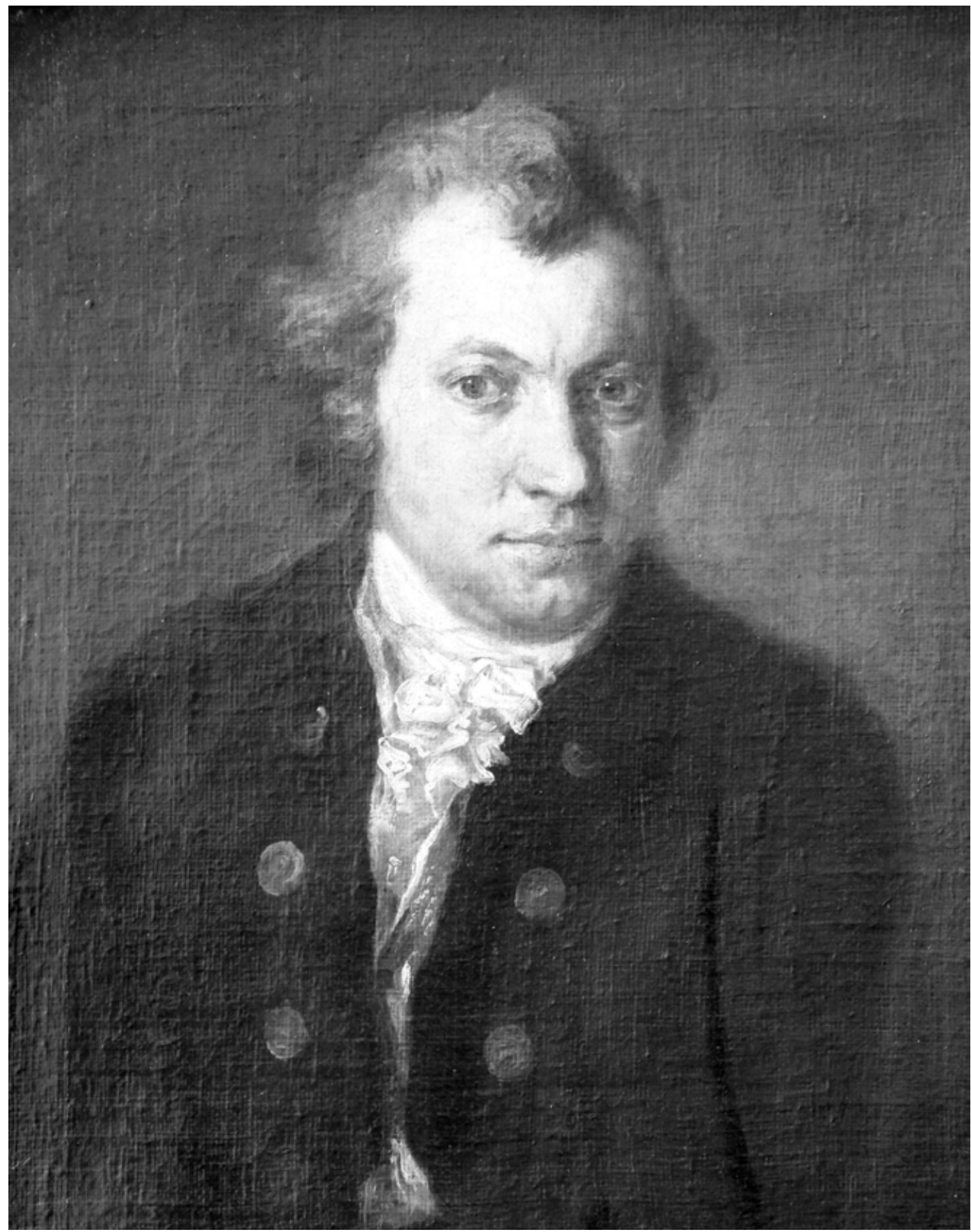

Illustration 1: Portrait of Heinrich Zimmermann by Johann Georg Edlinger (1741-1819) (Wiesloch Stadtarchiv. Photograph by Manfred Kurz, Wiesloch Stadtarchivar.)

Gazzetta Universale, 1 Aprile 1780; Wiener Zeitung, 23 May, 21 July, 1 August and 13 October 1781; Gazette van Gend, 19 July 1779 and 30 July 1781. 
The "new India Company, under the direction of Mr. Boltz," known as the Triestine Society, was announced by the press in Trieste on 17 August 1782, with a reference to the two vessels it would possess. ${ }^{11}$ The first of these ships was the Cobenzell, which Bolts had bought in England in November 1781, and named in honour of the vicechancellor of state, Count Philipp Kobenzl, a patron of the Imperial Company. The British Consul in Trieste, Nathaniel Green, noted in his February 1782 despatch: "a Ship is now in the River Thames loading for Naples, Ancona \& this Port, \& is to fit out here for the East Indies; she is called the Count Kobentzel \& is commanded by one Jno. Joseph Bauers, a Young Man who went with Bolts to Bengal." ${ }^{12}$ The London Courant for 9 May 1782 reported: "The Conte de Cobenzel, Bauer, is sailed from Falmouth to Trieste, when arrived off Malaga she is to give a signal for a Tuscan frigate, waiting there to convoy her up the Mediterranean."

Bolts hoped to send the Cobenzell to the North West Coast of America and round the world. He discussed his plan with the Emperor at an audience in Vienna in May 1782. His plan was for the Cobenzell to go round Cape Horn, take on furs in Nootka Sound, sell them in China and Japan, and return by the Cape of Good Hope. He engaged four British sailors who had served under James Cook, bought the sloop Trieste as a tender and sought letters of credence from the Emperor to various rulers at whose ports the ship would touch. He wrote to the Emperor on 30 June 1782, declaring that, "animated by the desire to open a most lucrative branch of commerce, although one completely novel, and at the same time to enjoy the glory of being the first among his faithful subjects to carry his August Standard around the Globe, he has purchased and fitted out a new Ship called the Comte de Cobenzell, to depart Trieste to make a voyage to the Coast of the NorthWest of America." He requested 150,000 florins from the Imperial treasury to finance the voyage. ${ }^{13}$ A letter from Bolts to his insurers in Ostend gives more information on the proposed venture:

On the Ship Count Cobenzell, a new Ship lately fitted out from London; of the burthen of between $500 \& 600$ Tons, commanded by John Joseph Bauer, an Hungarian, \& furnished with the Grand Signior's firmaun [permit from the Ottoman Court], 22 Guns \& from 72 to 85 Men, comprehending Captain \& Officers, about 20 Austrian Soldiers furnished by His Majesty, from Trieste, from whence she will be despatched in all September next, to the North West Coast of America \& from thence to Canton in China \& back to Trieste. For your private information, it may not be improper to observe to you that she is not to go on discoveries, but to Ports whereof the Longitudes \& Latitudes are perfectly known \& of which we have got the compleat plans, in particular those known by the names of Seduction River,

11 Report from Trieste of 17 August 1782 in The London Chronicle and The St. James's Chronicle, 5 September 1782.

12 Great Britain, The National Archives (TNA). Foreign Office Papers (FO) 97/61, Green to Stormont, 4 February 1782.

13 Wiener Haus-, Hof- und Staatsarchiv (HHStA), Staatskanzlei, Staatenabteilungen, Ostindische Compagnie-Triest-Antwerpen (OIC), Karton 2, Konv. 1781-1784, ff.45-47, Bolts to Joseph II, 30 June 1782. 
Sandwich's Sound \& King George's Sound [Cook Inlet, Prince William Sound and Nootka Sound]. Further, that besides other very able Officers, we have four who have been the voyage with the late Captain Cooke, \& two professed Astronomers. ${ }^{14}$

The British Ambassador in Vienna, Sir Robert Keith, reported the project in a letter to his foreign secretary, Charles James Fox, dated 26 June 1782:

I am informed that a Vessel is now building at Trieste which will be finished in the month of August, and is to be employed in the immediate service of His Imperial Majesty, for the very liberal Purpose of making the Tour of the World, in imitation of Captain Cooke's Voyages. The Captain of the Vessel will be an Austrian Subject, but a Mr. Dickson (an Englishman, who went round the World with Captain Wallis), Mr. Maerter Professor of Natural History, a Mr. Haydinger, a Botanist, a Painter, and some other Persons of Learning \& Curiosity are to carry the Emperor's Orders into Execution. I am told that they are to double Cape Horn, visit the Islands in the South Sea, and then proceed to China, where their Vessel (which is said to carry the Name of young Prince Kaunitz) will be sold, and the whole Crew will return to Europe in a large Vessel, to be held in readiness at Canton, and loaded with the Merchandize of China. ${ }^{15}$

George Dixon, a native of Kirkoswald in Cumberland, had been on Cook's third voyage to the Pacific as master armourer of the Discovery and not, as Keith said in his letter, on the 1766-1768 circumnavigation commanded by Samuel Wallis. The Wiener Zeitung of 29 June 1782 carried a report from Fiume that, "in the early days of this month, Herr von Bolts, Director of the Triestine East India Company, together with the English captain, Herr Digson, arrived in this city." In a dispatch to Fox of 8 July 1782, Consul Green in Trieste gave his understanding of Bolts's plans:

the Count Kobentzel is now on her way from London. She is to receive a Cargo here, one article of which is to be a large quantity of Quicksilver \& is to go from hence to the Brazils from whence She is to proceed to China; it is said also that Her Route will be by the Straits of Magellan. Mr Bolts has now with him at Vienna an Englishman named Dickson who was with Captn. Cook in one or more of His Voyages; they have also found out \& engaged a Man of Spire [Speyer] or Stutgard, who was with Dickson in the same Voyages. A Sloop of about Fifty Tons is just now finish'd here which is to be taken to pieces shipped on Board the Vessel abovemention'd, to be reput together \& being well armed, to trade upon the Coasts \& Rivers of South America with the Spaniards \&c. ${ }^{16}$

The Wiener Zeitung of 17 July 1782 announced the arrival at Leghorn on 3rd of

14 Provincial Archives of British Columbia, Additional Manuscript 223, William Bolts to Messrs. Wm. Herries, G. Keith \& Co., Vienna, 31 July 1782,

15 TNA FO 7/4, Keith to Fox, Vienna, 26 June 1782.

16 TNA FO 97/61, Greaen to Fox, 8 July 1782. 
that month of "the very fine and large Royal and Imperial Ship, named the Graf Kobenzel, under the command of Mr. John Joseph Bauer." The newspaper added, "It is understood that she will undertake a voyage to the Northwest of America, and return from thence by way of Canton to Trieste." The proposed voyage was announced in the Italian press in the following terms:

Vienna, 11 and 22 July. A subscription has been opened here on the account of Lieutenant Colonel Boltz, director of the Austrian East India company, for those who wish to take an interest in the cargo of his ship called the Conte di Cobentzel. This, which has been designated by H.M. to go round the world, will depart Trieste armed with 20 cannon under the command of Captain Baver, and will have on board an expert English astronomer, who has already made such a voyage under Captain Coock. The Vessel will proceed by the Cape Verde Islands, and from thence will go round Cape Hoorn passing on to the Islands of Taiti. From thence she will sail to the coast of California and proceed across the Pacific to China....Signor Marter, Professor of Natural History at the Theresianum College, and Signor Haidinger his assistant, are going to make the voyage round the world on the vessel which will depart for this purpose, as has been said, from the Port of Trieste. ${ }^{17}$

The four former members of Cook's crew were named in a dispatch from Green of 28 February 1783 :

Mr Bolts...means however, to retain in His Service, several Englishmen for Officers of the Ship in question, His Agent Mr Watts, (formerly in the Canada Trade) Mr Gilpin, an Astronomer, Dixon, \& Walker, English Seamen, \& Zimmerman, a German, which four last named were all with Capn. Cook in His last Voyage \& are kept by Bolts to assist in a similar Tour of the Globe, which appears to be a favourite project of his, expecting enormous profits from a Trade in Furrs, \& Gold Dust, on the Nth. West Coast of America, (Lat $47 \mathrm{Nth}$.). I have some reason to believe that He has also in Contemplation, something in regard to the Commerce of the New States of America, direct with China. ${ }^{18}$

Forty-seven degrees North is the latitude of Grays Harbour, Washington, first put on the map when it was discovered in May 1792 by Robert Gray in the Boston fur trader Columbia; " 47 " is probably a slip of the pen for "49," the latitude of Nootka Sound, which Bolts specified as his destination.

George Gilpin had in fact been on Cook's second voyage to the Pacific (17721775), in the Resolution, where he was assistant to the astronomer, William Wales. From

17 Gazzetta Universale (Florence), 13 Luglio and 3 de Agosto 1782. See also Gazeta de Lisboa, 30 de Agosto 1782: "Por todo o mez que vem sahirão daqui Mr. Marter, Professor de Historia Natural no Collegio Theresiano, e seu adjunto Mr. Hardinger, par darem hum gyro ao redor do mundo por ordem, e á custa do Imperador, para vantagem das Artes e Sciencias." TNA FO 97/61, Green to Grantham, 28 February 1783; see also Green to Fox, 9 May 1783. 
1776 to 1781 he was assistant at the Royal Observatory. He married Lydia Green on 20 May 1781 at St. Bartholomew the Less, London. Lydia was a niece of Charles Green, the astronomer on Cook's Endeavour voyage (1769-1771) and of Sarah Wales, the wife of William Wales. ${ }^{19}$

William Walker, from Glasgow was, like Dixon and Zimmermann, in the Discovery under Cook on the voyage to the North Pacific, as carpenter's mate. ${ }^{20}$

Johann Heinrich Zimmermann was born on 25 December 1741 in Wiesloch, just south of Heidelberg in the Palatinate. ${ }^{21}$ Leaving home in 1770, Zimmermann had a variety of jobs around Europe. He had trained as a "Guertler," the profession of a worker in precious and non-precious metals who made ornaments, jewelry, cutlery including swords, metal tools and implements. He spent time working at this in Geneva, Lyons and Paris before he arrived in London in 1776 where, after a short period of working in a sugar refinery, he joined the Discovery as an able seaman on 12 March of that year for James Cook's third voyage to the Pacific. ${ }^{22}$ He became the ship's coxswain in July 1776. During the voyage he kept a concise journal (contrary to orders) written in abbreviated German in a small notebook, which he afterwards used to write an account, Reise um die Welt mit Capitain Cook, published in Mannheim in 1781 and in Munich in 1783. A French edition was published in Berne in 1783, and a Dutch edition in $1784 .{ }^{23} \mathrm{He}$ had the help of a friend in writing it, according to Johann Reinhold Forster. ${ }^{24}$ The fame generated by the book led to Zimmermann being appointed in August 1781 by the Prince Elector of Bavaria, Karl Theodor, to the position of "Churfürstlicher Leibschiffmeister" (Master of the Prince Elector's Ships), where he was responsible for the fleet of hunting and excursion boats on Lake Starnberg. ${ }^{25}$

19 John Robson, The Men who sailed with Captain James Cook, John Robson's homepage, 31 March 2009, at: http://pages.quicksilver.net.nz/jcr/ cookmen3.html\#George\%20Gilpin.

J.C. Beaglehole, The Voyage of the Resolution and Discovery, 1776-1780 (Cambridge, Hakluyt Society, 1967), 1472; and John Robson, The Men who sailed with Captain James Cook, John Robson's Homepage, 31 March 2009, at: http://pages.quicksilver.net.nz /jcr/ vancouver5.html.

21 Most sources give 25 October 1741, but this is based on a misreading of December written as 'Xbris' on his baptismal registration; Manfred Kurz, "Heinrich Zimmermann of Wiesloch," Cook's Log 33, no.1 (2010), 3-12.

22 Friedrich Nicolai, Beschreibung einer Reise durch Deutschland und die Schweiz im Jahre 1781 (Berlin und Stettin, Bd.6, 1785), 692-3.

23 Henri Zimmerman, Dernier Voyage du Capitaine Cook autour du Monde (Berne: la nouvelle Société Typographique, 1783); H. Zimmerman, Reize rondom de Waereld met Kapitein Cook (Leyden : Honkoop, 1784).

24 Johann Reinhold Forster, preface to his translation of [John Rickman], Tagebuch einer Entdeckungs Reise nach der Südsee (Berlin, 1781). This, perhaps, was noteworthy in the days before publishers assigned editors to their authors as a matter of course.

25 Inamarie Kottmeier, "Das ungewöhnliche Leben des Heinrich Zimmermann, kurfürstl. Leibschiffmeister am Starnberger See," Vom Einbaum zum Dampfschiff, Bd 2, Starnberg (München, Förderverein Südbayerisches Schiffahrtsmuseum Starnberg e.V., 1982), 7-21; Noel Macainsh, "Sailor to Captain Cook: Some Notes on Heinrich Zimmermann and his 
On his way to Bavaria, Zimmermann visited George Forster in Kassel in January 1781 with his shipmate on the Discovery and fellow countryman, Barthold Lohmayer, who was native to that city. Forster, who had been with his father Johann Reinhold Forster on Cook's Pacific expedition from 1772 to 1775, was working in Kassel as professor of natural history at the Collegium Carolinum, a university preparatory school. He had gained this position in spite of his lack of formal qualifications thanks to Voyage round the World, his account of Cook's 1772-1775 expedition: the German version, Reise um die Welt, published in Berlin in 1778, had made him a celebrity in Germany. Forster afterwards wrote to Joseph Banks: "I have had a very ample detail of the late Voyage from the mouths of two Germans, who have made the voyage as common sailors \& who appeared very faithful in their accounts." ${ }^{26}$ When Zimmermann's book was published Forster wrote a review of it, criticizing some errors in it, but this did not prevent him from using information obtained from Zimmermann in his own essay, "Fragmente über Capitain Cooks lezte Reise und sein Ende."27

Shortly after arriving at Starnberg, Zimmermann accepted an invitation from Bolts to join the proposed voyage of the Cobenzell, and obtained leave from the Prince Elector to do so. ${ }^{28}$ The intended Imperial expedition was reported in the German press in July 1782, in the following terms:

The all-encompassing mind of the Kaiser attracts every kind of merit. While he abolishes the old abuses, gives new laws and makes happy his people, he also recognizes how much the sciences and useful arts contribute to the benefit of the state. In accordance with these ideas, he has caused several savants and artists, the Sub-director of the Natural History Cabinet, Heydinger, the Professor of Natural History, Märter, the Palace Gardener, Boos, and the Imperial Painter, Moll, to undertake a voyage round the world through the several lands of the two Indies, to perfect the various branches of natural science and to make new discoveries and observations in these fields. The ship designated for this illustrious expedition, the Graf von

Background, with a Portrait," Journal of the Royal Australian Historical Society 64, pt.1 (June 1978), 32-39. Robson, The Men who sailed with Captain James Cook, John Robson's Homepage, 31 March 2009, at: http://pages.quicksilver.net.nz/jcr/ cookmen11.html \#Heinrich\%20Zimmermann

26 Siegfried Scheibe (ed.), Georg Forsters Werke: sämtliche Schriften, Band 13, Briefe bis 1783 (Berlin: Akademie-verlag, 1978), 316, 318, 343, note 274, Forster to Joseph Banks, Cassel, 10 January 1781 ,

27 Göttingische Anzeigen (October 1781), reprinted in Horst Fiedler (ed.), Georg Forsters Werke: sämtliche Schriften, Band 11, Rezensionen (Berlin, Akademie-verlag, 1977), no.7 (review of Zimmermann). Georg Forster, "Fragmente über Capitain Cooks lezte Reise und sein Ende," Göttingisches Magazin der Wissenschaft und der Literatur, 6s Stück, 1780 (1781), 346-51; reprinted in Horst Fiedler, Klaus-Georg Popp, Annerose Schneider und Christian Suskow (eds.), Georg Forsters Werke: sämtliche Schriften, Band 5, Kleine Schriften zur Völker- und Länderkunde (Berlin: Akademie-verlag, 1985), 72-92, 687-690.

28 Staatsarchiv München, HRI 197v7, Briefprotokolle Gericht Starnberg, Band 1804; cited in Kottmeier (1982), 17. 
Cobenzl, will be supplied with necessaries and be in readiness by the beginning of August. ${ }^{29}$

The proposed voyage was announced to the press in Vienna on 22 July 1782 as a natural history expedition:

Vienna, 22 July. Signor Marter, Professor of Natural History at the Collegio Teresiano [the Imperial military academy], and Signor Haidinger his assistant, will both go on a voyage around the World in the Vessel that will, it is said, depart for this purpose from the Port of Trieste. ${ }^{30}$

Although the Emperor was initially enthusiastic, the venture eventually proved impossible to realize. The opposition of Bolts's Belgian financial partners in the Imperial Asiatic Company of Trieste and Antwerp was a principal cause of its not going ahead, and the Emperor also refused to provide financing for it apart from the expenses of his naturalists: in the autumn of 1782 it was abandoned. ${ }^{31}$ Bolts's letter to his Ostend insurers indicated that he may have had little real sympathy with the Emperor's scientific ambitions for the voyage. Instead of sending out a scientific expedition on an Imperial ship, the party of naturalists led by Franz Joseph Maerter went from Le Havre in April 1783 as passengers on the American frigate General Washington to Philadelphia. From thence they made their ways to South Carolina, Florida, the Bahamas and Santo Domingo (Hispaniola). ${ }^{32}$ George Dixon afterwards wrote concerning the failed venture:

So early as 1781, William Bolts, Esq; fitted out the Cobenzell, an armed ship of 700 tons, for the North-West Coast of America. She was to have sailed from Trieste (accompanied by a tender of forty-five tons) under Imperial colours, and was equally fitted out for trade or discovery: men of eminence in every department of science were engaged on board; all the maritime

29 Journal für rationelle Politik (Hamburg:Julius 1782), 176.

30 Gazzetta Universale (Florence), 3 Agosto 1782.

31 Guillaume Bolts, Recueil de pièces authentiques, relatives aux affaires de la ci-devant Société impériale asiatique de Trieste, gérées à Anvers (Antwerp, 1787), 110. Franz von Pollack-Parnau, "Eine österreich-ostindische Handelskompanie, 1775-1785: Beitrag zur österreichische Wirtschaftsgeschichte unter Maria Theresia und Joseph II," Vierteljahrsschrift für Sozial- und Wirtschaftsgesichte, Beiheft 12 (Stuttgart, 1927), 77. On the natural history objectives of the expedition, and how they were subsequently pursued, see Madeleine Ly-Tio-Fane, "A reconnaissance of tropical resources during Revolutionary years: the role of the Paris Museum d'Histoire Naturelle," Archives of Natural History 18, pt. 3 (1991), 323-362.

32 Helga Hühnel, "Botanische Sammelreise nach Amerika in 18. Jahrhundert," Franz Wawrik et al (eds.), Die Neue Welt: Oesterreich und die Erforschung Amerikas (Wien, Oesterreichische Nationalbibliothek, 1992), 61-78; Albert V. Carozzi and Marguerite Carozzi, "Franz Joseph Märter, travel companion of Johann David Schöpf in a journey from Philadelphia to Florida and the Bahamas in 1783-1784," Earth Sciences History 13, no.1 (1994), 5-2; Marianne Klemun, "Österreichische wissenschaftliche Sammelreisen nach den Amerikas, 1783-1789: Intentionen, Instruktionen und Implikation," Wiener Zeitschrift zur Geschichte der Neuzeit, 5 Jg., Heft 1 (2005), 21-35. 
Courts of Europe were written to, in order to secure a good reception for these vessels, at their respective ports, and favourable answers were returned; yet, after all, this expedition, so exceedingly promising in every point of view, was overcome by a set of interested men, then in power in Vienna. $^{33}$

At odds with his Antwerp backers, Bolts found himself declared bankrupt in midOctober 1782: Nathaniel Green noted in his despatch of 28 October 1782, "The Bankruptcy, happen'd about ten Days ago." 34 Although he possessed no capital himself, he was able to use his reputation as an expert in the Eastern trade to launch a new share company in 1783, the Triestine Society. ${ }^{35}$ Nathaniel Green wrote again to Secretary of State Fox from Trieste on 18 August 1783 that the:

Cobentzel will be ready to sail from hence in about three Weeks....Some Englishmen who are Officers on board are very much dissatisfied with $\mathrm{Mr}$ B. who refuses to pay them, as he promised when his Affairs were in disorder, and he engaged them to wait till this period. Some others whom he had also brought here to serve in his Expedition to the North West of America by Way of Cape Hoorn are now also in Dispute with him for their Pay and Discharge, both of which he refuses, and pretends he shall yet be able to put this Project in execution. This may be very uncertain, and I believe that he himself sees that this Country is not well adapted to his views nor can give hopes of Success to them. I know also that he has entered into Correspondence with Naples in the Affair. ${ }^{36}$

The Triestine Society sent the Cobenzell in September 1783 on a commercial voyage to the Malabar Coast by way of the Cape of Good Hope. ${ }^{37}$ On 17 th of that month, Bolts wrote from Trieste to the chief minister of the Neapolitan government, the Englishman Sir John Acton, reminding him that he had not had a reply to letters he had written to him on 16 and 23 July and informing him that "I have since despatched the ship Cobenzell, which sailed from this Port the 8th instant, richly loaded, on her voyage towards India and China. Not having received a timely answer from your Excellency, the projected voyage to the North West Coast of America must now be dropped, at least for this season." ${ }^{38}$ The four Cook veterans did not go with the Cobenzell on this voyage.

33 A Voyage Round the World (London, 1789), xx.

34 TNA FO 97/61, Green to Grantham, 28 October 1782.

35 Sir Richard Temple, "Austria's Commercial Venture in India in the Eighteenth Century," Indian Antiquary XLVII (April 1918), 85-92.

36 TNA FO 97/61, and British Library, Oriental and India Office Collections (OIOC), Miscellaneous Letters Received, E/1/73, no.121; quoted in Temple (April 1918), 92.

37 Wiener Zeitung, 15 and 18 January 1783. Temple (April 1918), 85-92. Fulvio Babudieri, Trieste e gli Interessi austriaci in Asia nei Secoli XVIII e XIX (Padova: CEDAM, 1966), doc.26, "Certificato azionario della Société Triestine."

38 Archivio di Stato di Napoli, Esteri, f.4211, Bolts all'Ammiraglio Acton, 17 September 1783, quoted in Giovanni Iannettone, Presenze italiane lungo le Vie dell'Oriente nei Secoli XVIII e XIX nella Documentazione diplomatico-consolare italiana (Napoli: Edizioni scientifiche 
After leaving Trieste, she proceeded to Marseilles, where she took in the principal part of her cargo and departed that port in December for Madeira where she took on wine and other provisions. ${ }^{39}$ The departure of the Cobenzell from Madeira on 6 April 1784 was reported in the London Morning Post of 2 July:

The Count of Cobenzel, Capt. Bauer, an Imperial East Indiaman, sailed from hence the 6th ult. her principal lading is wine, chests of coral, dollars, and about sixty cases of rich clocks and boxes of watches, that were purchased for the Trieste Society, by Mr. Bolts during his last journey, and are said to have been executed by some of the best workmen at Vienna, Paris, Geneva, and in England. They were sent hither [Madeira] from Marseilles, London, and Leghorn, and were said to be intended for the Emperor of China, and to be bartered with the Chinese Merchants of Canton for goods.

The departure of the Cobenzell from Madeira was delayed a month by adverse weather. That, and news of her arrival at Bombay on 14 August 1785, was reported in the London press in October 1785:

Trieste, August 27. The Directors of the Imperial East India Company have received letters from Bombay over-land (via Constantinople), informing them, that their ship, the Count of Cobenzel, John Joseph Bauer, Commander, had arrived at that settlement, and sixty cases of rich clocks and watches, the whole intended for the Canton market, to be taken on board a large ship of nine hundred tons burthen, carrying thirty guns, navigated by ninety men, to be called the Count de Belgioioso, and to proceed therewith direct to China... it is supposed that Captain Bauer would arrive at China early in the season, before any of the ships from Europe, which is the only chance they have of selling their cargo to any advantage, or of procuring one home, as the credit of the said Company is at a very low ebb, and they are so much indebted to the Chinese, as to render it a doubtful matter, whether the ship and property will not be seized for the payment of it. ${ }^{40}$

As Nathaniel Green intimated, Bolts still wished to carry out his North West Coast venture, and the Emperor consented in November 1782 to his request to place his proposal before the court of Catherine II of Russia. ${ }^{41}$ In his petition to the Emperor seeking his permission, Bolts promised that the expedition would sail from Trieste under

italiane, 1984), 302-3.

39 The Daily Universal Register, 10 October 1785.

40 The London Chronicle, The Morning Post, 8 October 1785, The Public Advertiser and The Daily Universal Register, 10 October 1785.

41 HHStA, Staatskanzlei, Staatenabteilungen, Ostindische Compagnie-Triest-Antwerpen (OIC), Karton 2, Konv. 1781-1784, f.6, Referat der Staatskanzlei, Kaunitz an Joseph II, 26 November 1782, cited in Pollack-Parnau (1927), 88. See also contract of 20 December 1782, HHStA, Ost-indische Compagnie (OIC) vi, and Hofkammerarchiv (HKA, Vienna), Commerz, Litorale 1749-1813, n.103, fasc.i-iv; cited in Walter Markov, "La Compagnia Asiatica di Trieste," Studi storici 2, no.1 (1961), 3-28. 
the Russian flag. ${ }^{42}$ He sent letters to Catherine II and to the Russian Vice-Chancellor I.A. Osterman, offering his services and ships for an expedition to the North West Coast of America by way of Cape Horn. He proposed this expedition, under the Russian flag and commanded by Russian officers, take possession of a port with the object of bringing a large part of the coast under Russian sway. He further proposed the formation of a company to operate from Kamchatka trading with the American coast, China, Japan the islands of the Pacific and the east coast of Africa. He would require a loan of 150,000 rubles to undertake the venture. ${ }^{43}$

The Russian Court did not accept the proposal, perhaps because Trieste was an unacceptable home port for a Russian expedition, but Bolts's initiative probably played some part in alerting the ministers of Catherine II to the need for action that led in 1787 to the decision to prepare a naval expedition to safeguard and promote Russian interests in the North Pacific. ${ }^{44}$ Unsuccessful with the Russians, Bolts then approached Joseph's brother-in-law, King Ferdinand of Naples (as mentioned by Green in his despatch). Joseph's younger brother Leopold, Grand Duke of Tuscany, referred in a letter to him of 31 March 1783 to Bolts's endeavours:

He told me that he counted on sending a vessel from Trieste this summer on his own account to the North of America to try the coasts where Captain Cook had been, that he lacked money to defray the expenses of its fitting out, that with your permission he had written to Russia to offer to that Court to make the voyage on their account, and that he flattered himself that the King of Naples would take part and give him funds, as well as the Roman

42 HHStA, Staatskanzlei, Staatenabteilungen, Ostindische Compagnie-Triest-Antwerpen (OIC), Karton 2, Konv. 1781-1784, ff.7-9, Bolts to Joseph II, 25 November 1782,.

43 Bolts to Catherine II, Vienna, November 1782, offering to lead a Russian expedition to the North West Coast of America, Kamchatka and China, Российский государственный архив древних актов, фонд Госархива [Государственный Архив Российский Империй], разряд XXIV (Сибирский приказ и управление Сибирью), дело 61 (Проект Капитана Г.И. Болтца об экспедиции к северо-западному побережью Америки 1782), [Rossiiskii Gosudarstvennyi Arkhiv Drevnikh Aktov, fond Gosarkhiva (Gosudarstvennyi Arkhiv Rossiiskoi Imperii), razryad 24: Siberian order and control of Siberia, delo 61 Project of Captain Bolts for an expedition to the north-west coast of America, 20ff.]; cited in Центральный Государивенный Архив Древних Актов СССР: Путеводитель [Tsentral'nyi Gosudarstvennyi Arkhiv Drevnikh Aktov USSR: Putevoditel'], Tome I (Moskow, 1991), 378. Bolts to Osterman, Trieste, 17 December 1782, Российский государственный архив древних актов (Rossiiskii Gosudarstvennyi Arkhiv Drevnikh Aktov/Russian State Archive of Early Acts, Moscow), fond Gosarkhiva, razryad 24, delo 61]; cited in Glynn Barratt, Russia in Pacific Waters, 1715-1825 (Vancouver: University of British Columbia Press, 1981), 89, 254.

44 James R. Gibson, “The Abortive First Russian Circumnavigation: Captain Mulovsky's 1787 Expedition to the North Pacific," Terrae Incognitae 31 (1999), 49-60; Robert J. King, "The Mulovsky Expedition and Catherine II's North Pacific Empire," Australian Slavonic and East European Studies 21, nos.1/2 (2007), 101-126. 
Propaganda and the Pope, as he would offer to take on board as many missionaries as they wished. ${ }^{45}$

As the King of Spain had patronage over all missionary activity in the Pacific and America, it is unlikely that the Propaganda would have responded favourably to Bolts's approach. He apparently had a more encouraging response from Naples, where King Ferdinand's Minister of Commerce and the Navy, General Sir John Acton, wanted to promote the kingdom's maritime trade. ${ }^{46}$ Zimmermann and Walker went to Marseilles to assist in the fitting out of the Ferdinand, a ship Bolts planned to send to the North West Coast under the Neapolitan flag. Bolts wrote to them from Paris on 7 July 1785:

Gentlemen-I have received from Mr Kirschbaum [captain/supercargo of the Ferdinand] at Paris the letters you have written me, relative to the orders come from Naples. You are mistaken in your apprehensions that this change will deprive you of service, as I shall explain to you after my arrival at Paris, where I shall return in a few days more. In the meantime continue your activity \& zeal in the service under the direction of Mr Rosaguti, \& I shall endeavour to settle every thing to your satisfaction soon, as also to have the pleasure of seeing you in Marseilles. ${ }^{47}$

Bolts wrote from Paris to Zimmermann, who by now was in Marseilles, with news on 7 May 1785:

Sir-In reply to have received your letter of 29th ult. \& am pleased with the detail you give me, as well as at the resolution taken by Mr. Kick [Bolts' banker in Marseilles] to continue the work till we get news from Naples. Before that time I hope to see him at his ease with respect to the funds. But I desire that neither you nor Walker will mention to any one in conversation any thing about Naples....We have good news of the Cobenzell which will be back in June or July. She is to touch at Malaga coming up the

45 Alfred Ritter von Arneth, Joseph II und Leopold von Toscana: Ihr Briefwechsel von 1781 bis 1790 (Wien, 1872), erster Band, 160. Bolts's proposal to the Office of the Propaganda Fide is most likely to be located at the Archivum Congregationis de Propaganda Fide (Rome), in the series Scritture referite nei Congressi, or in Lettere e Dereti della Sacra Congregazione e Biglietti di Monsignor Segretario.

46 "Plan pour les lettres patentes d'octroy exclusif proposé à être accordé par sa majesté le roi des Deux Siciles à Guillaume Bolts pour le commerce et navigation aux Indes Orientales, à la Chine et ailleurs, sous le titre de Société Royale Asiatique de Naples, pour le termes de 21 anneés," Archivio di Stato di Napoli, Esteri, f.4211; cited in Giovanni Iannettone, Iniziative di commercio con le Indie Orientali del Regno delle Due Sicilie (Napoli, 1967), 3ff; and in idem, Presenze italiane lungo le Vie dell'Oriente nei Secoli XVIII e XIX nella Documentazione diplomatico-consolare italiana (Napoli: Edizioni scientifiche italiane, 1984), 66-69; and in Aurelio Lepre, "Sui rapporti tra Mezzogiorno ed Europa nel Risorgimento," Studi storici 10, no.3 (Luglio-Sett., 1969), 556-7.

47 IISH, Vollmar Papers, Zimmermann, A4, f.13, William Bolts to Henry Zimmermann \& William Walker, London, 7 July 1785. 
Mediterranean. They have bought another large ship at Bombay [the Belgioioso] in which they are going to China. ${ }^{48}$

The London press carried a report from Trieste of 22 February 1786 that "The Comte Cobenzel East Indiaman arrived in this port the 18th inst. with a rich cargo" of saltpetre, tea, cassia, camphire, coffee, pepper and other merchandize. ${ }^{49}$ The return to Trieste of the Cobenzell under the command of John Fyffe and Bauer's purchase of "another ship" in India to go to Canton was reported in Vienna on 27 February $1786 .{ }^{50}$

A supercargo of the Swedish East India Company in Canton was gloomy about the prospects for the sale of the Belgioioso's cargo there. In a letter dated 25 February 1785 to a friend in London, he said clocks and watches were, as a result of an edict from Peking suppressing the customary presents, a "losing article." He commented further, "as their [Mr. Bolts and the Trieste Company's] credit with the Chinese is already bad, they will certainly meet with a disappointment, and indeed I know nothing like Mexico dollars at present for procuring a good homeward bound cargo." 51 The Belgioioso under Bauer went from Canton to New York, where she arrived in June $1786 .{ }^{52}$ Her arrival from New York at Dover was reported in The Daily Universal Register of 15 September, and the same newspaper published an extract of a letter from Ostend dated 24 September that said: "The Count de Belgioioso, Delartzh, on account of the East India Company, is arrived here from Bengal and China, her cargo consists chiefly of piece goods, with only a few chests of the finest teas, and one of spices, from Ceylon, at which island they touched on their way home."53 The Swedish merchant's fears were well grounded, as a letter of 20 November 1786 from an American correspondent in Boston published in the London press reported:

48 IISH, Vollmar Papers, Zimmermann, A4, f.7, William Bolts to Henry Zimmermann, Paris, 7 May 1785.

49 The Daily Universal Register, 20 March 1786; Gazette van Gend, 13 Maerte 1786.

50 Reported in the Gazzetta Universale (Florence), 11 Marzo 1786.

51 The London Chronicle, 26 November 1785.

52 The Connecticut Courant (Hartford), 19 June 1786. Bauer apparently made good use of his time in New York, as the following extract from a letter to the United States Ambassador in Paris, Thomas Jefferson, attests: "I understand that a Visit will be paid you by a Gentleman who is to be married to a Lady in this Town, and her Friends request the Favor of me to mention him in my Letters to you. The Gentleman's name is John Josh. Bauer a Lieutenant in his Imperial Majesty's Navy, and late Captain of the imperial East India Company's Ships Count de Cobensel and Count Belgioioso." John Jay to Thomas Jefferson, New York, 14 February 1878 (read 6 April 1787 at Marseilles), in Julian P. Boyd (ed.), The Papers of Thomas Jefferson (Princeton: Princeton UP, 1955), vol. 11, 145.

53 The Daily Universal Register, 30 September 1786. The Gazette van Gend of 25 September 1786 reported the entry into Ostend on the 22nd of "den Graeve de Belgiososo, kap. Joseph Bauer van China." The Public Advertiser carried a report from Ramsgate of 26 September that, "The Count Belgioioso, Baur, from China and New York, is arrived at Ostend." The London Public Ledger of 10 October 1786 carried an advertisement of the sale at Ostend by Messrs Keith and Co. for the Triestine Society of the cargoes of the Belgioioso and the Cobenzell and of the Belgioioso herself. 
The last American ship that arrived from China brought an account that the sale of all sorts of clockwork had received a severe check in consequence of an order from the Emperor that arrived at Canton whilst our ship [the Empress of China] was there, whereby the Viceroy and other great officers of state where directed to send no more presents of "Sing songs" (by which term clocks and watches are distinguished) on account of the great number that for several years past had been sent him, with which his palace was sufficiently crouded... The captain and supercargo of an Imperial EastIndiaman, called the Belgioioso, from Canton, consigned to Mr. Anthony Laspanard, at New-York, from whence she lately sailed after two months repair, confirmed the above intelligence, which must needs prove a heavy disappointment to the Trieste Society, to whom said ship belongs, and to whom it had also been recommended to send out sing-songs as promising the greatest profits. By the captain's account upwards of 10,0001. was accordingly invested therein, which to their great loss and mortification produced in barter for teas, even before the Emperor's mandate was known, no more than 40001. and those teas so greatly over-rated, that the same quantity might for specie have been purchased at least twenty per cent. cheaper. $^{54}$

Although Bolts had been in negotiation with Sir John Acton, the hopes for a voyage to the North West Coast under the Neapolitan flag in the Ferdinand came to nought: King Ferdinand gave Bolts a charter, modelled on that he had received from the Empress Maria Theresa in 1776, with a term of twenty-one years from 1786, for a Royal Indian Company of Naples (Regia Società del India di Napoli), but the Neapolitan government agreed to support Bolts only after he had made a successful initial voyage at his own expense and risk. ${ }^{55}$ With the Emperor's permission, Bolts then put his proposal to the Court of Joseph's brother-in-law, Louis XVI of France. The French response was more positive, as a voyage of discovery was already under consideration, and many of Bolts's ideas were incorporated into the expedition that sailed from Brest on 1 August 1785 under the command of Jean-François Galaup de La Pérouse. ${ }^{56}$ La Pérouse was a national hero who had destroyed the Hudson's Bay Company's Prince of Wales Fort and

54 The Morning Chronicle, 17 January 1787. "Sing-songs" were chiming clocks, Pidgin English for the Mandarin Chinese ziming zhōng: see J. M. Braga, "A Seller of 'Sing-Songs': A Chapter in the Foreign Trade of China and Macao," Journal of Oriental Studies 6, nos.1-2, (1961/64), 61-108.

55 Archivio di Stato di Napoli, Esteri, f.4211; cited in Lepre (1969), 557.

56 Robert J. King, "William Bolts and the Austrian Origins of the Lapérouse Expedition," Terrae Incognitae 40 (2008), 1-28 (presented at the Canadian Nautical Research Society Conference, Churchill, Manitoba, 2-7 August 2007). 
its dependent factories in a daring raid into the Bay in $1782 .{ }^{57}$ Bolts was given no part in the preparation or execution of the expedition, but was paid 1,200 louis d'or for "the communications useful for the Service which he has given." 58

William Walker wrote from Marseilles to Zimmermann in Trieste on 3 June 1786:

Dear friend-Last Thursday I Received a Letter from Mr Bolts And two Letters for you, one from Mr Bolts and the other I believe from Bavaria... You will see by the contents of Mr. Bolts letter that he is willing to give a Declaration that he sent for Us from trieste to Marseilles, with the Aprobation of General Acteon [Acton]. Mr. Audibert has drawn out the form of a Declaration which he wishes Mr. Bolts to certify. I inclosed that in a letter which I sent to Mr. Bolts last post. I am obliged to stop the process \& attend heare for the Answer... As soon as I have Gott Mr. Bolts Answer I shall go stright to paris \& arrange with Mr. Bolts if I can. I shall Write you Immediatly when things are settled heare \& as I go Right for paris You will write to me at that City. You have Mr. Bolts Address which will find me. Give my Compliments to your Wife... I Remain, your Sincere frind, William Walker. $^{59}$

George Dixon had gone back to England, where he attempted to interest Sir Joseph Banks and English merchants in the North West Coast fur trade. ${ }^{60}$ This resulted in the formation of a consortium under the leadership of Richard Cadman Etches, of which Dixon became a member with an appointment as captain of the Queen Charlotte. ${ }^{61}$ The similarity is notable between the plan of the consortium and that elaborated by Bolts, which was apparently communicated to them by Dixon. ${ }^{62}$ The proposal they submitted to the East India Company in April 1785 said:

57 Robin Inglis, "Lapérouse 1786: A French Naval visit to Alaska," in Stephen Haycox, James K. Barnett and Caedmon A. Ligurd, (eds.) Enlightenment and Exploration in the North Pacific, 1741-1805 (Seattle \& London: University of Washington Press, 1997), 49-64, nb 52; see also Inglis, "Hudson Bay 1782: La Pérouse reports to his mother," presented at the Canadian Nautical Research Society Conference, Churchill, Manitoba, 2-7 August 2007. Marseilles, 3 June 1786.

Archives nationales, Fonds de la Marine, 3JJ 389, f.1; quoted in Gaziello (1984), 50.

IISH, Vollmar Papers, Zimmermann, A5, ff.10-12,William Walker to Henry Zimmermann,

Dixon to Banks, 27 August 1784 and Banks to Dixon, 29 August 1784, British Museum (Natural History), Dawson Turner Transcripts of Banks Correspondence, vol. IV, ff.47-49; cited in David Mackay, In the Wake of Cook: Exploration, Science \& Empire, 1780-1801 (Wellington, NZ: Victoria University Press, 1985), 60-61.

61 George Dixon (Johann Reinhold Forster übersetzt), Der Kapitaine Portlock's und Dixon's Reise um die Welt (Berlin: Voss, 1790), Vorrede des Uebersetzers, 11; V.T. Harlow, The Founding of the Second British Empire, (London: Longmans, 1964), vol.2, 420.

62 Instructions to Portlock and Dixon, September 1785, quoted in [John Etches], $A$ Continuation of an Authentic Statement of All the Facts Relative to Nootka Sound (London: Fores, 1790), 18-29. The Etches consortium scheme is discussed in Robert J. King, "The long wish'd for object': Opening the trade to Japan, 1785-1795," The Northern Mariner/le marin du nord XX, no.1 (January 2010), 1-35. 
Some time ago Mr. Bolts assisted by the Imperial Asiatic Company proposed to make this attempt; they built a ship at Marseilles [the Ferdinand]-and procured some of the people who were round [the world] with Captain Cook - they made offers to a Mr. Dixon, a man of great abilities, and complete from his experience for such an undertaking - not meeting with encouragement here, he accepted the offer-but the affairs of the Company stopped it. $^{63}$

George Gilpin also went back to England and his wife, and was elected Clerk and Housekeeper for the Royal Society of London on 3 March 1785; he remained in these positions until his death in $1810 .{ }^{64}$ Heinrich Zimmermann and William Walker stayed in Bolts's employ in Marseilles. It was apparently at around this time Zimmermann married his wife, Barbara: the couple were portrayed in a pair of portraits painted around this time by Johann Georg Edlinger, the Bavarian Court Painter, for a gallery set up by a Munich book dealer containing pictures of noteworthy but not necessarily titled Bavarians. Zimmermann is dressed in his uniform of a captain in the Imperial service. ${ }^{65}$

George Gilpin wrote to Zimmermann from London on 17 February 1784. Zimmermann had apparently used the time he had spent at Trieste to learn navigation and qualify as a ship's officer: he asked Gilpin to procure him a chronometer in London and Gilpin's letter confirmed that this had been done and sent to him in Trieste, together with a navigational horizon, two penknives and two pairs of buckles which Dixon had bought for him. Gilpin congratulated Zimmermann on his recent marriage: "Give me leave my dear Sir, to congratulate you on you late marriage $\&$ to wish you all the happiness that is possible for the marriage state to aford-'tis no more than I expected would take place when we left you; I beg you will make my best respects to your good Lady, as likewise to our friend Mr Walker." Apparently Gilpin was still interested in making a voyage to the North West Coast, as he added:

The voyage which was talked of here has dropt at present as there is nothing but disturbance with our [Prime] Minister. I have yet that voyage at heart as much as ever \& will if nothing should be undertaken by Government do all that lays in my power to forward it elsewhere. It was a pitty that Mr Bolts

63 British Library, OIOC, Home Miscellaneous, H/494, f.366, “Additional Proposals relative to the establishing a Trade between the North West Coast of America and the Coast of Asia, the Japanese Islands \&ca, laid before the Court of Directors, 29 April 1785,"; also at British Columbia Provincial Archives, Victoria, A/A/10/G79 H494; quoted in V.T. Harlow and F. Madden, British Colonial Developments, 1774-1834 (Oxford, 1953), 24.

64 Robson, The Men who sailed with Captain James Cook, John Robson's homepage, 31 March 2009, at: http://pages.quicksilver.net.nz/jcr/ cookmen3.html\#George\%20Gilpin

65 48th Stuttgart Antiquarian Book Fair, http://www.ilab-lila.com/services/news.php (as at 21 April 2009). "Der Weltumsegler kehrt zurück nach Wiesloch," Die Rhein-Neckar-Zeitung, 18 March 2009; Kurz (2010); see also Rolf Schenk, Der Münchner Porträtmaler Johann Georg Edlinger: Monographie und Werkskatalog (München: UNI-Druck, 1983). 
could not carry it on as he was at such a Great expence with it. Mr Dixon has been in the Country these two [?] past, shall write to him to morrow. ${ }^{66}$

Gilpin wrote again to Zimmermann from London on 17 February 1784: "I have the pleasure to acquaint you that on board the Ship Thames Capt. Thomas Newstead there is a small box for you containing the things you desired me to purchase for you here, together with two Pr. of Buckles \& two Penknifes which Mr. Dixon desired me to send along with them, so that the Box contains a Watch made by Mr. Arnold, an artificial horizon by Dolland \& the two Pr of Buckles \& Penknifes mentioned above." Gilpin's letter continued:

I hear Black Fanny was brought to bed of a Boy on board the Cobenzel \& Christen'd John Joseph Bawer-I beg you will make my best respects to Mrs Zimmerman and your friend Mr. Walker. You will please likewise to make my respects to Mr. Bolts...I heard sometime ago that the English Consul Mr. Green had left Trieste but I believe he is not arrived yet in England; if he has not yet left \& you should see him any time please to make my respects to him... Mr Dixon is well. I had a letter from him a little time ago. $^{67}$

Dixon wrote from Paris to Zimmermann and Walker jointly on 16 March 1785:

Gentlemen-I Rec'd yours and am glad to find you are in good health, should have writ you before but not knowing whether I should stop hear or return to London I put it of[f] that when I did write I Acquent you which I now do for I return to morrow for London but Perhaps may be in France again shortly. I am Glad to find Mr Zimmerman is pleasd with his Watch. Mr Bolts has not spoke to me about sending mine to Mr Walker so that I shall take his Back with me but should Mr Walker want his at any time while I am in London if he will send me his good Bill for Twenty Guineas I will send his to him at Marsiels by shiping...I am Gentlemen Yours \&c Geo. Dixon. ${ }^{68}$

Dixon in the Queen Charlotte and his superior, fellow Cook veteran Nathaniel Portlock in the King George, set sail from Deptford in September 1785. Their instructions from Richard Cadman Etches, perhaps reflecting the influence of Bolts's ideas, stated that after they reached the North West Coast, they should "establish such factories as you shall see necessary," and that:

King George's Sound [Nootka], we should presume, not only from being centrical, but in every respect consistent with the intent of forming such establishment...After having made such establishments...you are to make the best of your way to the Kurile, Japanese islands, and likewise the coast of

66 IISH, Vollmar Papers, Zimmermann, A3, George Gilpin to Henry Zimmermann, London, 17 February 1784.

67 Ibid., George Gilpin to Henry Zimmermann, London, 13 April $1784 .$.

68 IISH, Vollmar Papers, Zimmermann, ff.4-6, George Dixon to Henry Zimmermann, Paris, 16 March 1785. 
Asia...the northernmost parts of the island of Niphon, the islands adjacent, the coast of Corea, Nankin, and China I presume are the most advantageous for the disposal of furs. If a factory could possibly be settled on the island of Matmi [i.e. Matsumae, or Yezo, now Hokkaido], or any other convenient island contiguous to the north part of the island of Niphon, if this could be done with safety, or even if a friendly intercourse could be opened with the natives, it would be accomplishing a great object; but this must be entirely discretional. ${ }^{69}$

No settlements were made. In correspondence with Sir Joseph Banks in 1788, Etches explained that his and his associates' aim in 1785 was to establish two small trading factories on the North West Coast but that but that being a private (non-government) venture, when Portlock and Dixon arrived on the coast, "their Powers of Government were not competent to the task - nor cou'd they form any Establishment with a certainty of it ever being prosperous, because they had not Powers to form any real government for the regulating the People, consequently all wou'd soon have been Anarchy and Confusion."70

Zimmermann seems to have had a similar plan. In his account of Cook's last voyage he had mentioned the willingness of the natives of the North West Coast to engage in trade, consisting mainly on their part of the furs of "beaver" (by which he meant sea otter), sable and seal. ${ }^{71}$ His journal contains an undated outline of a version of Bolts' plan for taking advantage of the sea otter trade on the North West Coast. His remarks on trade with Japan are taken word for word from James King's account of Cook's last voyage. ${ }^{72}$ He wrote in his journal:

My plan supposes fitting out two ships of 400 or 500 tons in Europe (with 18 months' provisions), which would cost around 8,000 louis d'or, declared ready for sea and to go out on the following System as though going on discovery, making their way around Cape Horn to the Marquesas Islands, there to take on water and refresh the crew. From there they would make their way directly to Owhyee [Hawaii] where the second would stay and stock with provisions and water. From thence to the North West Coast to seek refit on that coast. From Cape Blanco in 44 North to Alaska in 60 degrees I am convinced that it is possible that much fine discovery is still worth doing. It is said that Russia considers it not unimportant to settle it in time with colonists. In returning engage in trade, the article concerned being sea otter pelts, from my being convinced that it is not idle talk, collecting at least 2,000 in a space of 6 months, as in Kamchatka each would be worth

69 [Etches] (1790), 20, 23.

70 California State Library, Sutro Branch, Banks Papers, PN 1/6 and PN 1/7, Etches to Banks, 17 and 20 July 1788,; quoted in F.W. Howay, "Four Letters from Richard Cadman Etches to Sir Joseph Banks, 1788-92," British Columbia Historical Quarterly 6, no.2 (April 1942), 125-39.

71 F.W. Howay (ed.), Zimmermann's Captain Cook, translated by Elsa Michaelis and Cecil French (Toronto: Ryerson Press, 1930), 71.

72 James King, A Voyage to the Pacific Ocean (London, May 1784), vol.III, 440-1. 
from 30 roubles, and the same items can be sent to Okhotsk and from thence to Kiachta on the Chinese border, which is 1,400 miles by land, from whence the Chinese can gain a good profit by transporting them to Peking which is 700 miles further, and from thence to Japan, which is now inclined to welcome those who go with goods of value to Japan. It is also worth remarking that the southern route from Kamchatka to Japan can be made in 14 days or at the longest in 3 weeks. Who will now criticize me by pointing to obstacles in the way of a direct trade with Japan, to the hostility of this nation against the Europeans. They have trafficked with Russia, with those who go from the coasts of the smallest of the Kurile Islands to the Japanese border. This channel can be used to develop trade in harmony with this nation before another nation can. ${ }^{73}$

Having missed the opportunity provided by the American War of Independence to send a ship to the North West Coast undisturbed by British, American or French competitors, Bolts was apparently able to share in the only voyage sent there under the Imperial flag, that of the Imperial Eagle, the former English East Indiaman Loudoun, which in November 1786 sailed from Ostend under Charles William Barkley. ${ }^{74}$ This vessel was owned by a consortium led by John Reid, John Henry Cox and Daniel Beale. ${ }^{75}$ John Reid, as mentioned above, had been set up as Imperial consul and agent of the Imperial Asiatic Company at Canton in late 1780, having gone there in the Kaunitz, a ship his brother, Andrew, had sold to Bolts in Bombay. ${ }^{76}$ John Henry Cox was a clockmaker who had been permitted by the East India Company to reside temporarily at Canton in 1781 in order to collect debts due to his father's London firm for clocks delivered but not paid for by members of the Canton hongs. In Canton, he became a partner of Reid, using Reid's status as Imperial consul to avoid the East India Company's ban on private trading by British subjects. In April 1785, they sent the Sea Otter under James Hanna to the

73 IISH, Vollmar Papers, Zimmermann, A23, part 3, ff.18-19, Journal of Johann Heinrich Zimmermann..

74 Madeleine Ly-Tio-Fane, “A reconnaissance of tropical resources during Revolutionary years: the role of the Paris Museum d'Histoire Naturelle," Archives of Natural History, 18, part 3 (1991), 323-362, nb 337; Provincial Archives of British Columbia, A/A/20.5/L92, Log of the Loudoun/Imperial Eagle; Beth Hill, The Remarkable World of Frances Barkley, 1769-1845 (Sidney, 1978), 60; B.M. Gough, "Charles William Barkley," Dictionary of Canadian Biography (Toronto: University of Toronto Press, 1979), VI, 36-7; and Holden Furber, John Company at Work (Cambridge, Mass., 1948), 71; Louis Dermigny, Chine et l'Occident: le Commerce à Canton au XVIIIeme. Siècle (Paris: SEVPEN, 1964), tome III, 1155.

75 W. Kaye Lamb, "Barkley Papers," The British Columbia Historical Quarterly 6 (1942), 4950. Other members were the East India Company supercargoes at Canton, Henry Lane, William Fitzhugh and David Lance (Dermigny (1964), 1155).

76 British Library, OIOC, G 12/77, ff.81, 98, Canton Consultations, 27 September 1783; HHStA, Kabinettsarchiv, Nachlass Kolowrat, Karton 10, Nr.659, Plan of Proli, Benkens and Nagel for establishing a share company for trading with China, 1780; ibid., Karton 2, Band 182c. Pollack-Parnau (1927), 42,78, Reid to Zinzendorf, January 1785; Williamson ([1975]), $1-35, \mathrm{nb} 10$. 
North West Coast as the first venture to exploit the fur trade revealed by Cook's expedition. ${ }^{77}$ Daniel Beale was the purser of, successively, the HC ships Walpole and General Coote on voyages between London and Canton in 1783-1786. In 1783 he joined Cox and Reid in their ventures. Beale organized the voyage of the Imperial Eagle when he returned to London from Canton on the General Coote in August 1786. ${ }^{78}$ Beale's brother or cousin, John Beale, sailed in her as purser, but was killed in an affray with the natives on the North West Coast. ${ }^{79}$

Following the failure of the voyage of the Belgioioso, John Reid departed Canton on the HC Ship Ganges in February 1787, leaving Cox deprived of the protection afforded to the partnership by his Imperial consulship, but this was compensated in October that year by Daniel Beale returning to Canton on the French East India Company ship Princess Elizabeth, having secured the consulship of Prussia from the Prussian ambassador in London. ${ }^{80}$ The East India Company directors in London were informed by letter from their supercargoes at Canton that on 5 November 1787 the president of their Select Committee, Henry Browne, had "received a visit from Mr. Daniel Beale, who acquainted him, that he was appointed his Prussian Majesty's Consul at this place." ${ }^{81}$ The news of Beale's appointment was reported in the Indian and British press: "the Court of Berlin has appointed as Consul at China, Mr. Bale, who was lately the chief officer of General Coote; he has been naturalized, and is to enjoy as extensive powers as the French Consul lately did, and as the American does at present." $\$ 82$

Cox was ordered by the English East India Company to leave China but when he departed in April 1788 was able to entrust his affairs in Canton to Beale. The voyage of the Imperial Eagle was described in an article in the London press in late 1788 written by Cox as having been "fitted out by a Society of Gentlemen at Ostend," perhaps a reference

77 W. Kaye Lamb and Tomás Bartroli, "James Hanna and John Henry Cox: the First Maritime Fur Trader and His Sponsor", BC Studies 84 (1989-90), 3-36; and Clare Le Corbeiller, "James Cox: A Biographical Review," The Burlington Magazine 112, no. 807 (June 1970), 351-358.

78 Dermigny (1964), 1241. Beale returned on the HC Ship General Coote, which arrived in England in early August 1786, as reported in The London Chronicle, 12 August 1786.

79 Daniel and John Beale, Charles William Barkley, John Henry Cox and his father and brother were all listed in The London Chronicle of 12 August 1786 as subscribers to the erection of a statue in honour of the prison reformer, John Howard (Howard himself rejected the proposal).

80 The Public Advertiser, 17 June 1788; Williamson, (1975), 1-35. Alexander Walker, An Account of a Voyage to the North West Coast of America in 1785 \& 1786, edited by Robin Fisher and J.M. Bumsted, (Vancouver: Douglas \& McIntyre, 1982), 202. The Ganges arrived at Portsmouth on 25 July 1787, as reported in The Morning Chronicle, 26 July 1787.

81 "Extract of a Letter from the Select Committee of Supercargoes at Canton to the Court of Directors, dated 16th Feb. 1787," published in The Public Advertiser, 17 June 1788. Henry Browne was the president of the Select Committee; East India Company, Bengal, Supreme Council, An Authentic Copy of the Correspondence in India between the Country Powers and the Honourable the East India Company's Servants (London: Debrett, 1787), vol.1, 53. 
to the Triestine Society. Having reached Nootka in June 1787, she traded southward along the American coast, arriving at Macao with her furs on 8 November. ${ }^{83}$ The expedition was apparently profitable, as an article in The Public Advertiser of 24 June 1788 reported that the Lowdon (i.e., Loudon) had been, "purchased in the Thames by a society of Gentlemen...to try their fortunes in the Sea Otter Trade, which has turned out beyond their utmost expectation. The vessel was freighted at, and sailed from Ostend in the middle of December, 1786... After taking in his cargo, \&c. \&c. Captain Berkeley [Barkley] proceeded to Macao, where he disposed of his furs at an amazing price." It was originally intended that the Imperial Eagle would make three voyages to the North West Coast, Japan and Kamchatka, reflecting Bolts's ideas, but when she reached Canton after her first season she no longer had the protection of Reid's Imperial consulship, and Daniel Beale on behalf of the owners sold her under threat of retaliation from the East India Company for breaching its monopoly. ${ }^{84}$

The Imperial Company of Trieste and Antwerp flourished despite the opposition of its rivals, the English and Dutch East India Companies, during the period when Britain found itself at war with Holland and France as a development of the American War of Independence. The Imperial Company benefited from Austria's neutrality during this conflict by being able to send its ships to Canton while its rival companies were prevented from doing so. An article in the French press reporting the prospective voyage of the Cobenzell commented: "This is a new proof that Austrian shipping is profiting from the present war to extend its commerce to all parts of the world." ${ }^{85}$ When the war ended, the Dutch and English companies returned in a rush to Canton, which raised the price of Chinese tea and other goods there and caused a glut of them when the ships returned to Europe. ${ }^{86}$ The Company's downfall in February 1785 was reported in the British press:

The efforts of the Emperor to extend the commerce of his subjects have received a considerable check by the failure of the Asiatic Company of Ostend and Trieste which is estimated at 20,000,000 livres Tournois. This event, which has given a severe blow to the whole trade of the Austrian Netherlands, is said to have been hastened by the Dutch, who procured bills to be drawn on the Company from Paris, to the amount of 800,000 livres,

83 "New Fur Trade," The World, 6 and 13 October 1788, and The European Magazine (November 1788). The Imperial Eagle is described as belonging to the Austrian East India Company (that is, the Imperial Company of Trieste) in F.W. Howay, A List of Trading Vessels in Maritime Fur Trade, 178 -1794 (Ottawa: Royal Society of Canada, 1930), 115.

84 Hill (1978), 60; F.W. Howay, "Early Navigation of the Straits of Juan de Fuca," The Quarterly of the Oregon Historical Society XII, no.1 (1911), 9; Williamson, (1975), 16.

85 Journal politique, ou Gazette des Gazettes(Septembre 1782), premier quinzaine.

86 Ernest van Bruyssel, Histoire du Commerce et de la Marine en Belgique (Bruxelles, 1851), tome III, 299; see also Giorgio Gilibert, "Il mercante, il banchiere e l'imperatrice: l'avventura coloniale della Compagnia Asiatica di Trieste," Roberto Finzi, Loredana Panariti e Giovanni Panjek (eds), Storia economica e sociale di Trieste, Volume II, La città de traffici, 1779-1918, (Trieste: LINT, 2003), 3-20. 
which were presented in one day, and protested for want of payment. These protests alarmed those who had deposited their money in the Company's stock; and each demanding immediate payment, Count Proli the director was obliged to abscond. The failure of this Company will contribute to prevent the smuggling of East-India goods into this country. ${ }^{87}$

Smugglers, of course, found other ways. The trade from the Austrian Netherlands to India which had been recommenced by Bolts and the Imperial East India Company was continued after the collapse of that company by a group of Belgian and English merchants headed by the Vicomte Edouard de Walckiers, whose family had played a part in the story of the Ostend Company which traded to India earlier in the eighteenth century and who, together with the Marseilles banker Kick, had been one of the biggest shareholders in the Imperial Company. ${ }^{88}$ The British merchants were mainly represented by the Brussels bankers, Charles Herries \& Co. William Bolts' company, referred to as the Société Triestine à Trieste, was apparently also connected with this group. ${ }^{89}$ From 1787, this association sent several ships to India from Ostend, the first of them being the St. Joseph. In the following years the ships Concordia, Belgioioso, Ville de Vienne, Henriette and Comtesse de Trautmannsdorff went to India. These voyages were undertaken exclusively to India, since the Chinese forbade trade to the Imperial flag until the debts which the Imperial Company had incurred in Canton, including 12 percent annual interest, were met. As Walckiers and his associates naturally did not want to become involved in that matter, China remained closed to their trade, while India and Mauritius remained the destination of around a dozen ships, until the French Revolutionary Wars put an end to these enterprises in the mid-1790s. ${ }^{90}$ The London Public Advertiser of 24 April 1787 carried an article that said:

It is a disagreeable reflection, though true, that the two ships fitting out at Ostend for China under the Emperor's flag, the Beljiosa and La Concordia (the latter was the Duke of Grafton, late in the East India Company's service) are both manned with English officers and seamen. This information comes from an Englishman, who is going out Mate: the wages they give as the cause.

Heinrich Zimmermann used the offices of Charles Herries \& Co. in London to find employment with Walckiers as ship's master to take the Concordia from Ostend to India in $1787 .{ }^{91}$ Walckiers wrote to him from Brussels on 5 May 1787, the day on which

87 The Edinburgh Magazine (May-June 1785), 571.

88 Helma Houtman-De Smedt, "The ambitions of the Austrian Empire with reference to East India during the last quarter of the eighteenth century," Chaudhury Sushil (ed.), Merchants, companies and trade: Europe and Asia in the early modern era (Cambridge: Cambridge University Press, 1999), 225-239, nb 235.

89 Furber (1951), 137; Heinrich Benedikt, Als Belgien österreichisch war (Wien: Verlag Herold, 1965), 197-198.

90 Pollack-Parnau (1927), 100-102; Michael Horvath \& Hannes Zimmermann, Österreich Maritim: Die frühen Jahre (Wien: Verlag Österreich, 1995), 80.

91 IISH, Vollmar Papers, Zimmermann, A6, f.11, M. Mullens to Zimmermann, London, 26 
his contract was signed:

Sir, You have herewith copy of the letter I have delivered you for Mr Neale Supercargo of my Ship the Concordia authorising him to assist you in your own affairs beyond what is specified in your agreement, and as I so not grant favours of the same nature to others I have no doubt that you will do everything in your power to deserve the continuance of my good opinion by the great care $\&$ attention I expect you will pay to my interest. ${ }^{92}$

Concordia cleared Ostend on 18 May, crossed over to Deal and by February 1788 arrived at Bombay. ${ }^{93}$ The vessel returned to Ostend on 23 November $1788 .{ }^{94}$ The cargo the Concordia took from Ostend to Bombay had been transported from London on the Walckiers ships, the St. Joseph, the Nancy and the Sampson. On her return from India in November 1788, the Concordia under Zimmermann was reported to have stopped at night off the Isle of Wight for a part of her cargo to be smuggled into England, before proceeding to Cowes and thence to Ostend. The rest of her cargo of India and China goods was sold at Bruges by George Keith and Co. associates of Herries and de Walckiers. ${ }^{95}$ William Bolts apparently also had some involvement with these firms. An advertisement in The St. James's Chronicle of 27 December 1788 said:

On Monday the 26th of January, 1789, will be sold by Publick Auction, at Bruges, in Flanders, The CARGO of the Imperial Ship Concordia, Captain Henry Zimmerman, from Bombay, consigned to Messrs George Keith and Co. of Ostend, consisting of about 1600 Bales of best Ahmood Cotton Wool, much superiour in Quality and Clearness to any hitherto imported; 2300 Bags of Saltpetre; and various other Articles, viz. Patna Rice, East-India Indigo, Betel Nut, Cassia Flowers, Couries, Cautch, Coculus Indicus, Buge Bunt, Cornelian Stones, and Oil of Sandal Wood (a most exquisite and costly Perfume), Samples of which may be seen by applying to Mess. George Keith and Co. of Ostend.

Dixon's ship the Queen Charlotte returned to England in September 1788, and on 15 December he wrote to Zimmermann:

By this day's post I Received a Letter from you of the third of this Month. I am extremely Glad to hear of your being in Good health but am sory the

February 1787.

92 The favours were advance payments to Mrs Zimmermann, an advance payment of $£ 220$ to be made to him in India and the right to purchase "small articles" in India on his own account. IISH, Vollmar Papers, Zimmermann, A6, f.4, E. de Walckiers to Zimmermann, Brussels, 5 May 1787.

93 Gazette van Gend, 21 August 1787 and The St. James's Chronicle, 21 August 1788.

94 Gazette van Gend, 27 November 1788.

95 List of sales at Ostend, printed as an appendix to a memorial on the case of the Antonetta, Algemeen Rijksarchief, Van Hogendorp MSS (1913), 144, and British Library, India and Oriental, Auditor's References 4, Capt. Chas Cobb of HM Scout Downes to the Court of Directors, 16 November 1788; cited in Furber (1951), 138. 
Voyage has not answered your Expectations - you say the Watch in $\mathrm{Mr}$ Arnold's hands is the only thing that now keeps you from returning into the Country. I am sory to say you must Expect yet to stay longer before you rec'd it...You have favored me with an order for one of the Books of the Voyage [Dixon's A Voyage Round the World] if you can contrive to send any person to caul for it when out shall send none [one] out... Should you see Mr Bolts My Comp[liments] To him. I am Dear Zimmerman, Yours \&c Geo. Dixon. ${ }^{96}$

After the return of the Queen Charlotte to England in September 1788, Dixon retained an interest in the North West Coast and in the search for the long-sought North West Passage, in the existence of which he retained a strong belief. In 1789 he met with Alexander Dalrymple, the Examiner of Sea Journals for the East India Company and an influential advocate of maritime exploration, and the Under-Secretary of the Home and Colonial Office, Evan Nepean. In July 1789 he urged on Nepean the need to take up Dalrymple's plan for a settlement on the North West Coast to prevent the Russians, Americans or Spanish from establishing themselves there. He said: "Upon the whole I am afraid if something is not done and that immediately this valuable Branch of Commerce will be lost to this Country." 97 On 20 October 1789 he wrote to Sir Joseph Banks regarding the expedition being fitted out under the command of his former Discovery shipmate, Henry Roberts for, as was reported publicly, discovery in the South Seas. He offered suggestions on the type of vessels that would be suitable and proposed the Queen Charlotte Islands as the best place to form a settlement on the North West Coast to promote the fur trade. ${ }^{98}$ The expedition was eventually taken to the North Pacific under the command of another of Dixon's former shipmates on Cook's last voyage, George Vancouver. William Walker went with this expedition as a surgeon's mate in the Chatham, commanded by William Broughton, the companion ship to Vancouver's Discovery. Walker Point, British Columbia and Walker Cove, Alaska, were named after him. ${ }^{99}$ In May 1790 the Hudson's Bay Company appointed Dixon to lead an expedition

96 IISH, Vollmar Papers, Zimmermann, A4, ff.4-6, George Dixon to Henry Zimmermann, London, 15 December 1788.

97 TNA Colonial Office Papers (CO) 42/72, ff.24-31, Dixon to Evan Nepean, 14 July 1789, and at Public Archives of Canada, Ottawa, Q series, vol.49, p.354, printed in Report on Canadian Archives 1889 (Ottawa, 1890), 29; cited in Barry M. Gough, "The Northwest Coast in Late 18th Century British Expansion," in Thomas Vaughan (ed.), The Western Shore (Portland Historical Society and American Revolution Bicentennial Commission of Oregon, 1975), 48-80, nb 67; TNA CO 42/21, ff.57-62, unsigned memorandum to Nepean on the need to make a settlement on the North West Coast, September 1789, cited in Mackay (1985), 84, 117.

98 Dixon to Sir Joseph Banks, 20 October 1789, in The White Knight Chapbooks, no.3 (San Francisco: The White Knight Press, 1941). A copy of this rare booklet is held at the Vancouver Public Library, Vancouver, BC. This letter is also reproduced in Richard H. Dillon, "Letters of Captain George Dixon in the Banks Collection," British Columbia Historical Quarterly XIV, no.3 (1950), 167-171.

99 John Robson, “British Columbia place-names," John Robson's homepage, 31 March 2009, 
overland from the western coast of Hudson Bay to the Pacific, but this venture was subsequently cancelled. ${ }^{100} \mathrm{He}$ may have been living at Gosport, near Portsmouth, teaching navigation as a book, The Navigator's Assistant, was published in 1791, written by a Captain George Dixon, R.N. (although in fact, Dixon was not a Royal Navy captain). Dixon, by now with a wife, Ann, went to Bermuda via New York in February 1794, with the intention of taking up the trade he had originally trained for as a silversmith/jeweller and, with the encouragement of the local government, setting up a school of navigation. The Bermuda Gazette in April 1794 advertised: "George Dixon, jeweller from London." The same newspaper reported that Dixon's wife Ann, "lately from England," died in childbirth in May 1794: she was buried at St George, Bermuda on 20 May 1794. Dixon was left with his only child, Marianna. He himself died soon after on 11 November 1795, as confirmed by a notice in the Cumberland Pacquet in February 1796: "[died] November 11 at Bermuda, Capt Dixon, the circumnavigator, a native of Kirkoswald in this county." The orphaned Marianna Dixon married a Bermudian merchant, Charles Bryan Hayward, in 1814. ${ }^{101}$

George Gilpin, as well as retaining his position with the Royal Society, was also Secretary to the Board of Longitude from 1801 to 1809 . He wrote several papers and made studies of magnetic dip and variation. After he died, his family was left in poor circumstances and members of the Royal Society contributed to a fund for the family. His daughter, M.A. Gilpin, petitioned the Board of Longitude in 1827 for payment of remuneration that was still outstanding. ${ }^{102}$

On the eve of quitting his post in Trieste to take up that of consul in Nice, Nathaniel Green wrote to Zimmermann in Salzburg on 6 April 1787, disclaiming any knowledge of William Bolts or his affairs, "unless that He was last heard from at Antwerp \& still talks of coming to Vienna." He added with reference to Bolts's financial difficulties: "The effects $\mathrm{He}$ has here will I suppose be sequestered by several Claimants." ${ }^{\prime 103}$ Bolts is said to have attempted to revive his fortunes in France, setting up an enterprise near Paris, but the outbreak of war with Austria and Britain once again destroyed his hopes. ${ }^{104}$ He returned to England in 1800-1801, where he attempted unsuccessfully to interest the East India Company in obtaining supplies of copper from Anatolia to sell in India. ${ }^{105}$ He then moved to Lisbon where in the 1760 s, before joining

at: http://pages.quicksilver.net.nz/jcr/ vancouver5.html

100 B. M. Gough, "George Dixon," Dictionary of Canadian Biography (Toronto: University of Toronto Press, 1979), IV, 217-9.

101 Duncan L. McDowall, “Captain Dixon's Last Port of Call: The Mystery of George Dixon's Last Years," Bermuda Journal of Archaeology and Maritime History, 14 (2003), 7-21. See also Robson, The Men who sailed with Captain James Cook, John Robson's homepage, 31 March 2009, at: http://pages.quicksilver.net.nz/jcr/ cookmen3.html\#George\%20Dixon

102 Robson, The Men who sailed with Captain James Cook, John Robson's homepage, 31 March 2009, at: http://pages.quicksilver.net.nz/jcr/ cookmen3.html\#George\%20Gilpin

103 IISH, Vollmar Papers, Zimmermann, A6, f.16, Nathaniel Green to Henry Zimmermann, Trieste, 6 April 1787.

104 Michaud frères, Biographie universelle, tome 5 (Paris, 1812).

105 Bolts to Hugh Inglis, London, 20 August 1800; cited in Willem G. J. Kuiters, The British in 
the English East India Company, he had worked in the diamond trade. He made his last will in Lisbon in August 1805 and died, it is said, in a Paris poorhouse (hôpital) in 1808. ${ }^{106}$

A Russian translation of Zimmermann's account of Cook's last voyage had been published in St. Petersburg in 1786 and $1788 .{ }^{107}$ Perhaps as a long-delayed response to William Bolts's proposal of November-December 1782, Zimmermann was asked in 1789 to plan a Russian expedition to the Pacific. Although he submitted plans, Russia was then engaged in wars with the Ottoman Empire and with Sweden, and the expedition never eventuated. ${ }^{108}$ In 1791-1792 he again took a ship, the Edward, to India for Edouard de Walckiers. ${ }^{109}$ The advent of war with revolutionary France put an end to the trade with India from the Austrian Netherlands, and Zimmermann returned to Munich. He retired to Starnberg in 1804 and died there on 3 May $1805 .{ }^{110}$ His surviving letters and journal, now held at the International Institute of Social History (IISH) in Amsterdam, provide valuable source material on the schemes of William Bolts and on the origins of the maritime fur trade on the North West Coast.

Bengal, 1756-1773: A Society in Transition seen through the Biography of a Rebel: William Bolts (1739-1808) (Paris: Indes savantes, 2002), 175, 186.

106 William Bolts's will made in Lisbon on 12 August 1805 and proved in London on 7 September 1808, National Archives, Kew, National Archives, Kew, PRO, PROB 11/1485, sig.710, cited by H.V. Bowen, entry on William Bolts in the Oxford Dictionary of National Biography (Oxford University Press, 2004), Vol.6, 496-7.

107 Г. Циммерман, Последнее Путешествие около Света Капитана Кука. СПб., Изд. П.Б. 1786 [G. Tsimmerman, Posliedneye Puteshestviye ekolo Svieta Kapitana Kuka - Captain Cook's Last Voyage Round the World] (St. Petersburg: P.I. Bogdanovich, 1786); cited in E.V. Govor, Bibliografiia Avstralii, 1710-1983 (Moskva: Nauka, 1985), 65.

108 IISH, Vollmar Papers, Zimmermann, A9, f.4, Jacovleff to Zimmermann, St. Petersburg, 16 October 1789.

109 IISH, Vollmar Papers, Zimmermann, A10, ff.4-5, Bletterman to Zimmermann, 24 April 1791.

110 Kottmeier (1982), 21. 